\title{
"The Freemasons are useful to the regime": An analysis of the representations of Freemasonry in cinema and its utility on reinforcing or criticizing the establishment
}

\author{
"Los Masones son útiles al régimen": \\ Un análisis de las representaciones de la Francmasonería en el cine y \\ su utilización para reforzar o criticar el orden establecido
}

\author{
Felipe Côrte Real de Camargo \\ Universidad de Bristol, Reino Unido \\ felipecortereal@gmail.com
}

Recepción: 7 de noviembre de 2018/Aceptación: 15 de noviembre de 2018.

doi: https://doi.org/10.15517/rehmlac.v10i2.34724

Keywords

cinema; freemasonry; history; representations; state of exception.

Palabras clave

cine; masonería; historia; representaciones; estado de excepción.

Abstract

This article addresses the relations between the language of cinema and some representations that this media may show on Freemasonry. The three chosen movies deserve attention for their representativeness. Freemasonry has become a recurrent theme in historical studies and combined with this phenomenon the Fraternity has been going through a greater public exposure. This public image is formed, mainly, by works of fiction, and through its leading vehicle, the cinema. On analysing in three movies a commonality in their approach is sought for, between images presented -about and by- Freemasonry in this social product of cinema.

\section{Resumen}

Este artículo trata las relaciones entre el lenguaje del cine y algunas representaciones que este medio puede mostrar sobre la Francmasonería. Las tres películas elegidas merecen atención por su representatividad. La Francmasonería se ha convertido en una temática recurrente en los estudios históricos, y estos combinados con el fenómeno de la gran exposición que la Fraternidad está teniendo. Esta imagen pública está formada, principalmente, por obras de ficción, siendo el cine su principal vehículo. Al analizar estas tres películas, se pretende hacer una aproximación entre las imágenes presentadas sobre la Francmasonería en este producto social que es el cine. 


\section{Cinema and History}

Far from being a new intersection, the interface, or interpenetration, between cinema and history is as old as the seventh art. In 1898, a Polish pioneer of cinematography, Bolesław Matuzewski, wrote an essay called "Une nouvelle source de l'histoire: création d'un depot de cinematographie historique", in which he exposes his theory that cinema, for being animated photography, would be capable of offering a truthful testimony of facts. By doing so, cinema would also control oral testimony, thus enabling an image bank of the important facts, or in Matuzewski's words "a deposit of historical cinematography".

We know that the project of the Polish author had not materialised in the way he predicted, nevertheless, besides the question on cinema/images and the apprehension of "real", the arrival of images changed, in an indelible way, the understanding of the historical process. This happened not just because of its documental value, like some authors predicted, but also for its aesthetical value and other variables (i.e. representation, reception, narrative, politics) which concern the field of historical studies.

\section{Freemasonry}

The fraternity that we recognised as Freemasonry, would be better off categorised as a practice since it doesn 't have a canonical form ${ }^{1}$. Therefore, the field of research dedicated to this topic has been heading towards a broad definition, the one of Freemasonries, giving space and a proper framework to this diverse phenomenon. Briefing, Freemasonry is a sociability with fraternal structure that have in its pillars the values of liberty, fraternity and relief. Being an initiatic order, it presents its teachings through morality plays and grades these learnings in a degree system.

Although Freemasonry searches to link its origins to events previous to their actual formation in the $17^{\text {th }}$ century, its true beginning is, temporally, explicit ${ }^{2}$. It is in mid- $17^{\text {th }}$ century that we have the first registers of the process of acceptance of people strange to the mason's craft ${ }^{3}$ in the guilds. These men, called "accepted", were from different trades, or

\footnotetext{
*A previous version of this article was presented in the "XIV Encontro Estadual de História da ANPUH-SC" in the thematic symposium "Modernities: History, Languages and Fiction", in August 2014.

${ }^{1}$ Although Modern Freemasonry, or the Grand Lodge system, had its start fairly dated and located, the variations and diversity of masonic rituals are evident. Its structure show patterns, as analysed by Snoek (2006, 87-108), but its diffusion caused innumerable variations, hence unsuitable to establish a canon.

${ }^{2}$ David Stevenson, The Origins of Freemasonry Scotland's Century, 1590-1710 (Cambridge: Cambridge University Press, 1990).

${ }^{3}$ I am referring here to the actual trade of stone worker.
} 
even noblemen, but in its majority were merchants and shop keepers, the newly born "middling sort".

Hobsbawm, in his article on proletarian's rituals, highlights that the model which gave birth to Freemasonry would become one of the most copied among the modes of sociability of the working class ${ }^{5}$. The decline of the trading guilds and the initiation of members alien to the guilds mark the beginning of the modern Freemasonry. Masonic historiography classifies the practice and period linked to the guilds as "operative masonry" and the one consisting of "accepted" masons only as "speculative freemasonry". This classification refers to the nature of the work, the former manual, material work, and the latter symbolic, intellectual.

The end of the $18^{\text {th }}$ century and the whole $19^{\text {th }}$ century are crucial periods for the construction of contemporary Freemasonry. Several movements wielded a strong influence on Freemasonry and were, in some way, a product of its impact, the Illuminist philosophy, in its French aspect as much as in the German Aufklärung, the French Revolution, the codification of Spiritism, the Rosicrucian and Cabalistic mysticism, aside from the $19^{\text {th }}$ century occult revival. All of them left a strong imprint, branding Freemasonry with its compelling characteristics: syncretism ${ }^{6}$.

Although scrutinization of the early days of Freemasonry is a hard task, specially its transition from operative to speculative, there is a foundational landmark that is almost undisputed: the establishment of the Grand Lodge of London and Westminster, in 1717, or 1721 , according to doubts casted by recent scholarship ${ }^{7}$. Since the $19^{\text {th }}$ century the, then, United Grand Lodge of England is regarded as the "mother lodge of the world" 8 , acting as an umpire for masonic regularity.

After the $17^{\text {th }}$ century, Freemasonry spread around the world. Its models of ritual and sociability were vastly copied by a succession of friendly and fraternal societies, trade unions and syndicates. To build a "general history" of Freemasonry requires a systematization of thousands of works that had been produced by both historians and amateurs. The multiplicity of this narratives led us to the concept of Freemasonries, but at the same time it doesn't make Freemasonry an impossible topic, or a hermetic one for that matter.

\footnotetext{
${ }^{4}$ George Rudé, Hanoverian London 1714-1808 (London: Secker \& Warburg, 1971).

${ }^{5}$ Eric J. Hobsbawm, Mundos do Trabalho (Rio de Janeiro: Paz e Terra, 2000).

${ }^{6}$ Despite contemporary revival of views of syncretism as a "downgrade", I understand the phenomenon in a historically natural light, as in Diderot's entry in the Enciclopédie were he defines syncretism as a process of concordance of eclectic sources, with all its "drawbacks".

${ }^{7}$ Andrew Prescott and Susan Sommers, "Searching for the apple tree: revisiting the earliest years of organised English freemasonry". In Reflections on Three Hundred Years of Freemasonry: Papers from the QC Tercentenary Conference edited by John Wade (London: Lewis Masonic, 2017).

${ }^{8}$ James W. Daniel, “UGLE External Relations 1950-2000: policy and practice”, Ars Quatuor Coronatorum 117 (2005): 147.
} 


\section{Anti-Freemasonry}

There is a major tendency nowadays to call anti-Freemasonry every article, opinion or questioning with some kind of opposition to the Order. Nevertheless, one must differentiate what is criticism to Freemasonry as such, being regarding its structure, philosophy and/or organization and what is criticism derived from prejudice or distortions propagated since the $17^{\text {th }}$ Century, that is to say, since the structuring period of modern Freemasonry.

Several are the examples and stories on anti-Freemasonry, for a brief and systematic analysis, I will promote a synthesis. Since Freemasonry was systematized in England, antiFreemasonry was its inevitable by-product. The nuances and motivations of the discourses against Freemasonry acquired vigour and suffered mutations, what made their permanence possible until today. Among anti-Masonic discourse it is possible to identify three main currents that gave birth to the others. Masonic author João Ivo Girardi schematized it in a very didactic way:

Three successive themes supported the anti-Masonry of the $19^{\text {th }}$ Century: a) the Anglophobe theme: According to its defenders, Freemasonry would be only a cover-up for the English Intelligence Service; b) the anti-Semite theme: Freemasons would be just puppets of the Jews. Jewish high finance, mainly the Rothschild, would be hidden behind Freemasonry. c) the Luciferian theme: the true meaning of Freemasonry would be the hidden demoniac activity in Lodge ${ }^{9}$.

Thus, anti-Masonry has been one of the main fuels to fan the flames of the "conspiracy theories". However, the spread "masonic secret" helped to feed the imagination of those nurturing a relation of love, hate or curiosity with the Fraternity. Hence, Freemasonry became a key element in the puzzle of the conspiracy theories that, given its nature, are all self-fulfilling prophecies.

\section{Cinema and Freemasonry}

Freemasonry has been a recurrent theme in cinema, explicitly, as part of the context or as a back-story. For example, in the movie El Angel Exterminador (Buñuel, 1962); among a surrealistic plot, that criticizes indelibly the bourgeoisie, there are several subtle Masonic references, differently, the movie From Hell (Hughes, 2001), uses Freemasonry as a key piece of the plot. It must be remembered that an always updated list of movies

\footnotetext{
${ }^{9}$ João Ivo Girardi. Do meio dia à meia noite: vade-mécum maçônico (Blumenau: Nova letra Gráfica e Editora, 2006 ), 30.
} 
related, in any level, with Freemasonry, can be found at the website of the Grand Lodge of British Columbia and Yukon.

Yet in the first years of cinema as an entertainment, Freemasonry was the subject of one of Bobby Bumps' adventures. Bobby Bumps was the main character of a series of animations produced by Bray Productions, between 1915 and 1925. Such animations were released by Paramount Pictures and were part of the Paramount Package, a bundle of short movies and animations that were screened in theatres previously to the movies. As defined by Kristian Moen "Focusing on a rambunctious young boy, Bobby Bumps, the films typically presented a series of humorous situations that resulted from his playful schemes and general unruliness" 10 .

In the animation Bobby Bumps starts a lodge (Hurd, 1916), the main character calls his neighbour to be part of his "masonic lodge". Notably, there is no masonic lodge at all, being Bobby Bumps' objective is only to prank his friend, like they were part of a ritual of initiation. For being the theme of a cartoon, a mass entertainment, remains clear that Freemasonry was not an obscure topic for the American society in the 1910s.

Bobby Bump marks the debut of Freemasonry in cinema, since then, the Craft has been an habituée of the seventh art. As formulated by Michèle Lagny, historians, when in front a movie archive, may question themselves about which movies to prioritize since two main aspects will be considered: the aesthetical value and their value as a testimony ${ }^{11}$. However, in the movies addressed in this article we have both aspects, since not just the analysis of its production context offers elements that attest its strength as testimony, but also its aesthetical aspects present crucial data about the topic to be focused on this article.

The feature that these movies have in common, beside the fact that they touch the thematic of "Freemasonry", is that they were produced within a state of exception" ${ }^{12}$ and extreme political polarization. Thus, I will try to understand how the reception, and the further production, of a given representation of Freemasonry took place in these three different, although with their similarities, contexts. Firstly, as a representation aiming to transform the fraternity in a pariah willing to destroy society, secondly, as a space for the development of desires for independence, but that can be dangerous, and thirdly, as showing the banality and servility of an order that upkeeps the status quo, and that even though its swallowed by it.

It is important to highlight that the term "representation" is being used in accordance to the understanding of Moscovici and his view deriving out of social

\footnotetext{
${ }^{10}$ Kristian Moen, "Imagination and Natural Movement: The Bray Studios and the "Invention" of Animated Film. In Film History 27, no. 4 (2015), 135.

${ }^{11}$ René Gardies org., Compreender o Cinema e as Imagens (Lisboa: Edições Texto \& Grafia, 2007).

${ }^{12}$ Concept developed by Carl Schmitt and expanded by Giorgio Agamben homonymous book. For Schmitt's legal theory, the state of exception is an ability within sovereignty to suspend the rule of law in the name of an alleged greater good or public order. Agamben refers to it as a paradigm of government, a strategy to rule, and outrule enemies.
} 
psychology, in which the author recognises the two main functions of the representations, which are:

a) In the first place, they conventionalize the objects, people or facts that they meet. They give it a definitive form, localize it in a determined category, and gradually set it as a model of a determined type, distinct and shared by a group of people. All the new elements join this model and synthetize themselves in it $^{13}$.

b) In second place, representations are prescriptive, that is to say, they impose themselves on us with an indescribable force. This force is a combination of a structure that is present even before we start to think, and of a tradition that decrees what must be thought ${ }^{14}$.

Thus, I will try to understand in which way these conventions on what Freemasonry is, occurred. Also, in which way these conventions inscribe themselves in society, synthetizing views on the Order, and how these movies prescribed ways to perceive that social phenomenon, that is Freemasonry, in their respective societies.

\section{Les Forces Occultes (1943) - Anti-Freemasonry as Nazi propaganda}

The movie "Les Forces Occultes" is a French production from the period known as Vichy France (Régime de Vichy). Nevertheless, there is a habit of crediting all the French political actions of this period to the Nazi occupation, although it was a prime mover, it is important to underline that some segments of collaborationists were not a mere consequence of threaten. The French State (État Français), even though a puppet government of the Nazis, gave way to the current ideology, namely the ones of sectarian religious values with an authoritarian mindset. This blend was translated into the trinomial Work, Family, Homeland (Travail, Famille, Patrie), and, important to this article, it also rekindled anti-Freemasonry and anti-Semitism, or even "anti-Cosmopolitism" as suggested by Jean-Robert Ragache, former Grand Master of the Grand Orient de France ${ }^{15}$.

The half-length film, director by Jean Mammy, under the alias of Paul Riche, it's a genuine expression of the Nazi aesthetics. Using the same narrative style, the movie also

\footnotetext{
${ }^{13}$ Serge Moscovici. Representações Sociais: Investigações em Psicologia Social (Petrópolis: Vozes, 2009$), 34$.

${ }^{14}$ Moscovici, "Representações Sociais", 36.

${ }^{15}$ A propos de Forces Occultes. Director: René Le Moal. Production: Les éditions Véga. 16 min e 26 seg. Available in http://www.dailymotion.com/video/x81q5t forces-occultes-le-complot-judeo-ma_news
} 
dips the same camera ${ }^{16}$ effects already seen in classics of the Nazi cinema as "Der Triumph des Willens" (Triumph of the Will, 1935), "Jude Suss" (1940) and "Der Ewige Jude" (The Eternal Jew, 1940).

Freemasonry was officially banned from the French territory since August $13^{\text {th }}$ 1940, due to a law prohibiting the operation of "secret societies", undoubtedly the aim of such legislation was the Craft and its most important bodies ${ }^{17}$ in France, the Grand Orient de France and the Grande Loge de France. An example of this focus in the bigger bodies is that only in the beginning of 1941, smaller obediences, mixed and feminine, were hit by the decrees declaring their constitutions null. Immediately, masonic archives fell in hands of Nazis and French collaborationists; massive police inquiries were undertaking, lists with names of French freemasons were published in the newspapers, and around three thousand people lost their jobs for being members of the Order.

More than the paranoia of the Judeo-masonic-communist complot, Nazis and collaborationists feared that the capillarity of Freemasonry would fit up the French resistance, what actually ended up happening, increasing its efficiency. Freemasons were used to silence and secrecy, they recognized each other discreetly and among its members there were from postmen to industrialists. These improbable relations between these men caused the Vichy government to establish a task force to solve this puzzle.

It is in this context that the Propaganda-Abteilung Frankreich (Department of Propaganda in France) commissioned the director, and mason, Jean Mammy to film "Les Forces Occultes", released in 1943. The movie was a mix of the confiscated masonic archives, when it came to parts of the ritual and regalia, to the Nazi paranoia, regarding the political action and character of its members. However, it is not the aim of this article to verify what is true, or accurate in the movie, and what it is not.

Jean-Marques Rivière, a well-known anti-Masonic, anti-Communist, and antiSemite pamphleteer, wrote the script and in the movie première declared that it was "a political and revolutionary act". The plot tells the story of a French congressman (Pierre Avenel) that, as can be noticed in the initial sequence of the movie, in which he is giving a speech at the French National Assembly, is an organic intellectual of the national-socialist ideology. Thus, insulting all the parties and its members, accusing them to throw France in a crisis, and to put the country on the brick of war, congressman Avenel claims that this "strategy" was benefiting both, left and right, and doing so builds to the public an image of integrity beyond suspicion.

The conspiracy plot unravels a clear division of good against evil, honest fighting dishonesty, since the beginning of the movie. Notwithstanding, the plot, in this case, is a

\footnotetext{
${ }^{16}$ Director and screenwriter Jean-Patrick Lebel used the term camera which encompass the whole process from the filming to the final edition. For its conceptual simplicity, I will take the same stance.

${ }^{17}$ Masonic bodies, or obediences, are administrative entities that group three or more lodges. Every Masonic lodge is affiliated to a body, or obedience.
} 
backdrop to the real movie decoy: the first recorded re-enactment of a masonic ritual. Some pieces of divulgation would even highlight that the rituals used were "in accordance with the ones used by the Grand Orient of France".

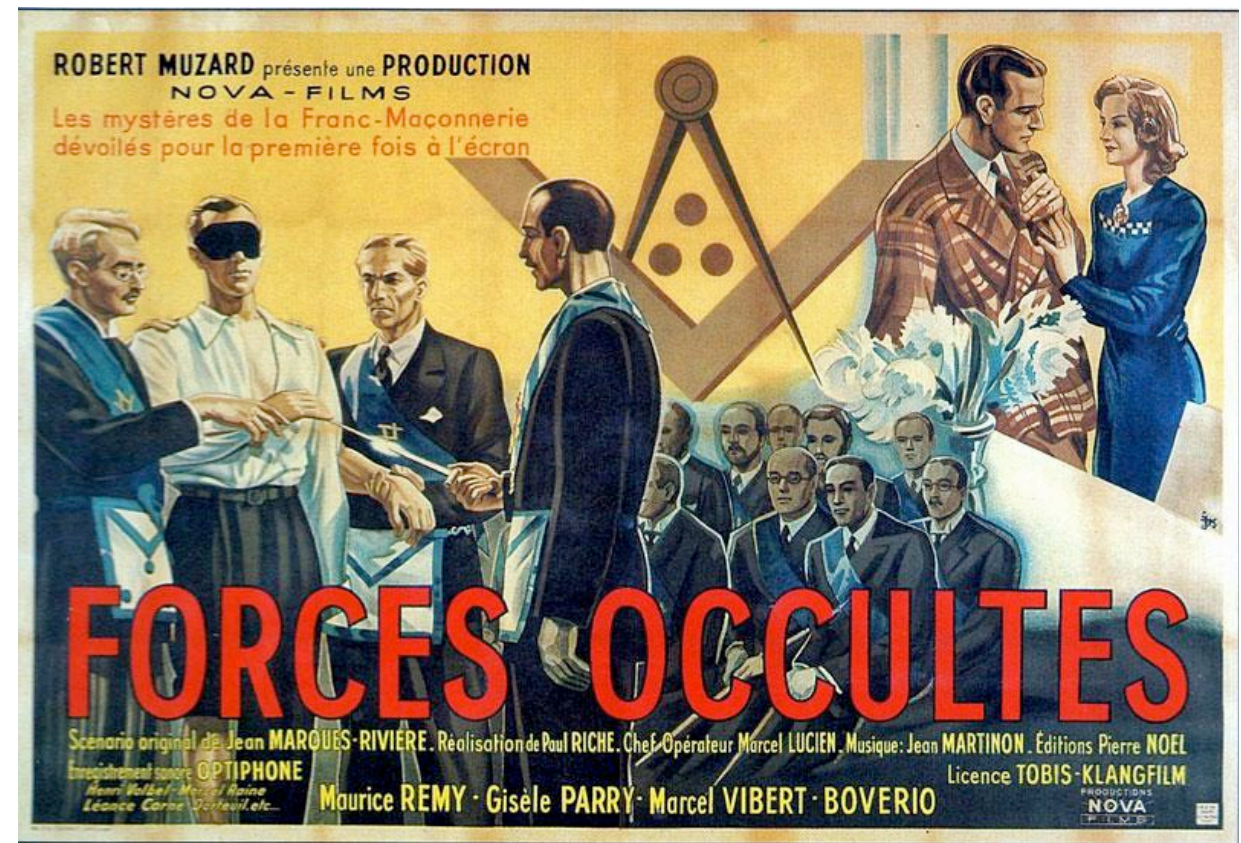

(Above) The poster announced, "The mysteries of Freemasonry unveiled for the first time on the screen" (Below)The lodge gets prepared to receive Avenel

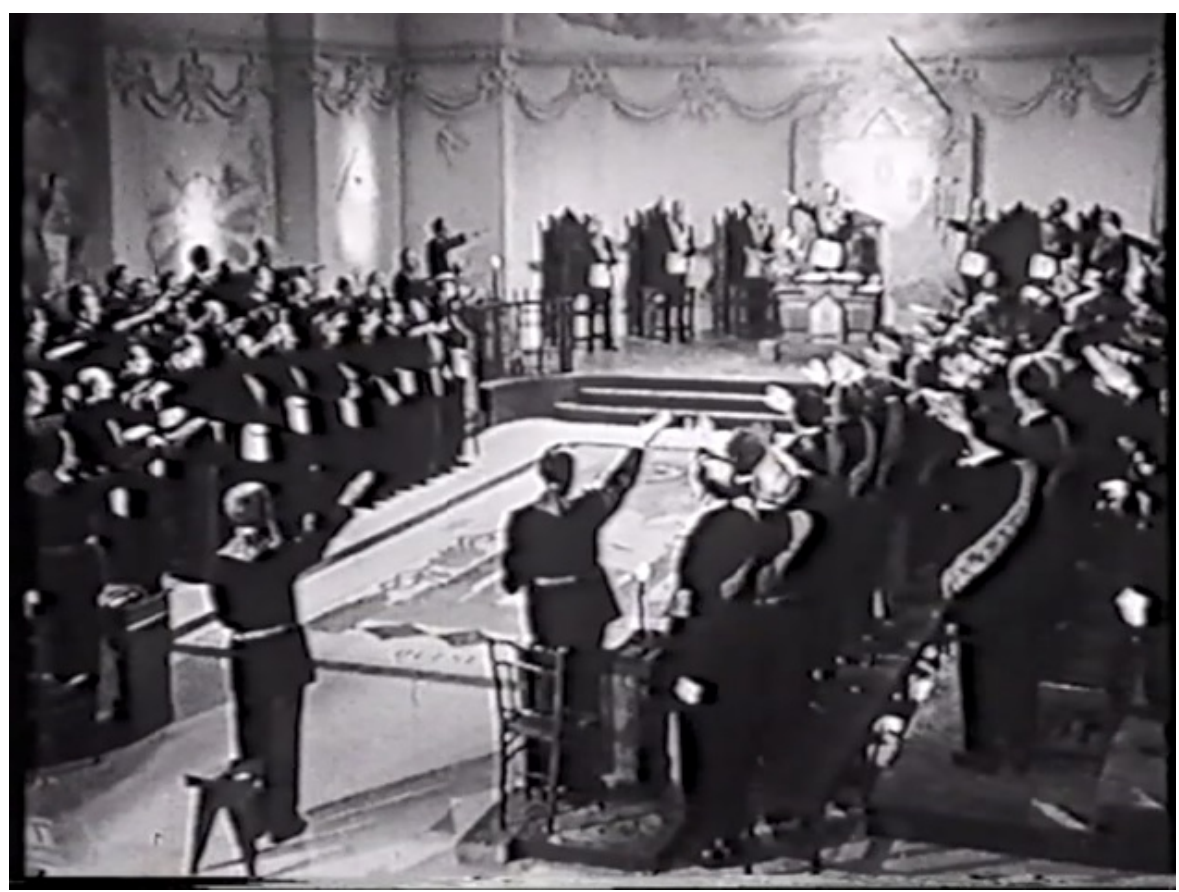


As soon as Avenel is initiated on Freemasonry, he starts to be asked shady favours by his now brothers, in name of fraternity. Moreover, the movie refers to some famous scandals of the Third Republic, the period between 1870 and 1940 in France, linking them to different freemasons asking Avenel for aid in their private affairs. Such scandals are referred using the covers of newspapers, including "L'Anti-Maçon", directed by Leo Taxil $^{18}$, one of the most famous propagandists against Freemasonry.

Consequently, Avenel decides to leave the lodge after realizing that France's entrance in the war against Germany (the Second World War) was a Judeo-MasonicCommunist complot. Recurring to a narrative element that it is perceivable in the other movies analysed in this article, the final part of the movie, leading to Avenel resignation, shows an open discussion about politics inside the lodge - something appalling for any Masonic ritual. Nevertheless, this scenario, i.e. Freemasons orchestrating political moves in lodge, is appealing to the narrative that Freemasonry is, primarily, an obscure association. Avenel's decision of leaving the lodge is met with disapproval, and finally to an attack that ends up his life, not after a moving speech about the dangerous of Freemasonry, to his wife, on his death bed at the hospital.

The final scene shows the triumph of evil against good. The Orator of the lodge, that through the whole movie is portraited as an evil character, is shown laughing, in his masonic regalia, with the Globe in flames in front of him. Suggestively, the expression "The End" (Fin) is presented within a star of David, alluding to the Jewish conspiracy.

\footnotetext{
${ }^{18}$ One of the pseudonyms of Marie Joseph Gabriel Antoine Jogand Pagès (1854-1907), journalist and writer, famous for his anti-Ecclesiastic and anti-Masonic writings.
} 


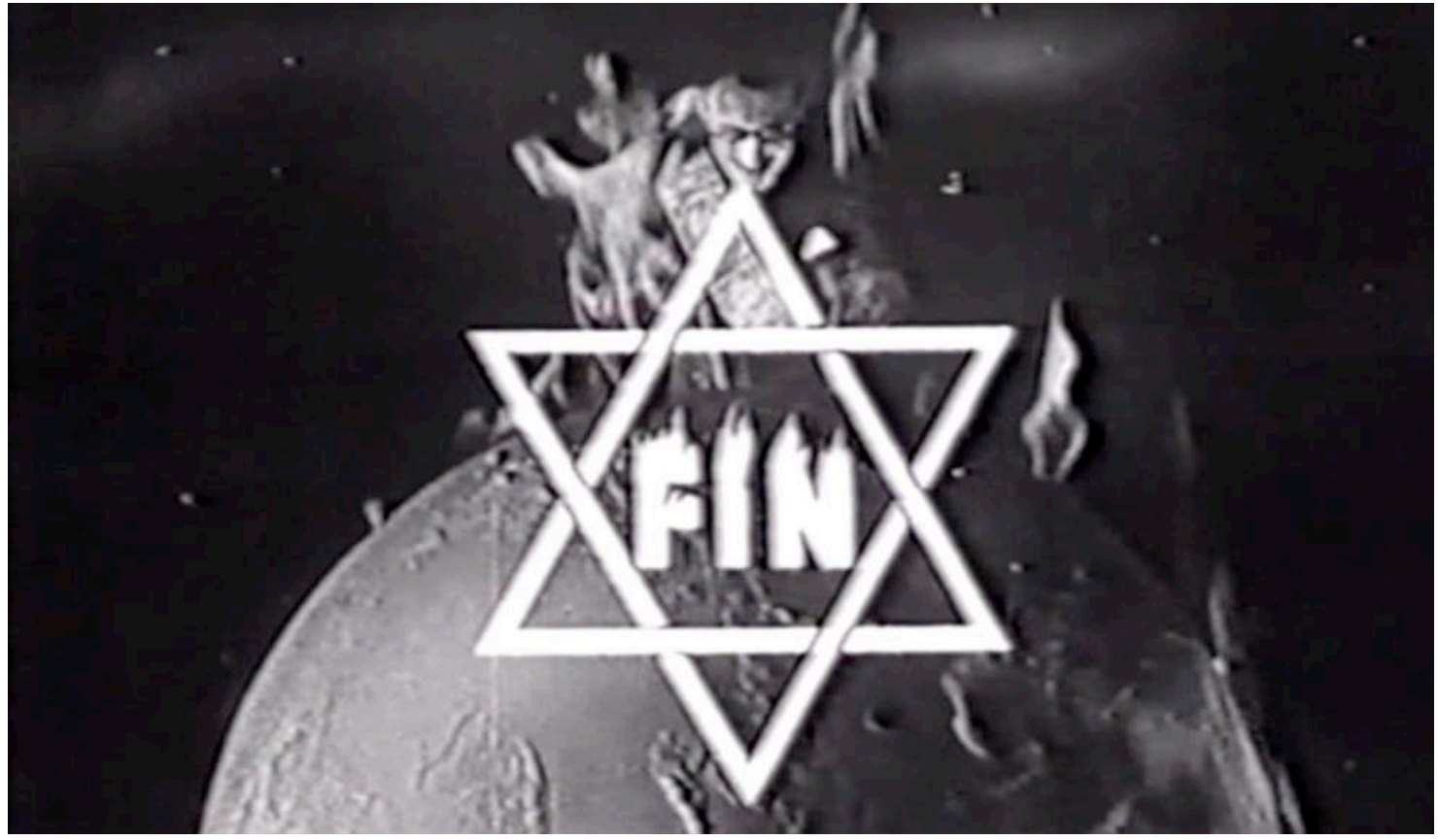

The final image, showing the judeo-masonic victory, hence the triumph of evil.

Important to realize, that this film has the same narrative structure of propaganda as defined by F. Chevassu in the Journal Image et Son (Sound and Image):

1. Emotional reaction, defeat, 2. To state the obvious: France was not prepared for war, 3. Projection of the spectator in the character: Pierre Avenel, honest, blazing patriot who refutes that shameful war, 4 . The character, hence the spectator, victim of scapegoats, 5. The instinctive condemnation of those scapegoats ${ }^{19}$.

Obviously, the use of the movie "Les Forces Occultes" as an anti-Freemasonry, anti-Semitic or anti-Communist, did not stop with the Vichy France. The movie, available online, counts hundreds of thousands of accesses, and the comments left by users show that the work of Mammy still echoes as a formative, or a reinforcement, of a certain image of Freemasonry for most people.

\footnotetext{
${ }^{19}$ Chevassu, F. "Forces Occultes". Image et Son: La Revue do Cinema. Paris: Union Française des Oeuvres Laïques d'Éducation par l'Image et par le Son, numero 188 (novembre, 1965), 36.
} 


\section{Independência ou Morte (1972) - Freemasonry as part of the "Brazilian Miracle"20}

The movie Independência ou Morte (Independency or Death), took to the big screen the official and obliging version of the proclamation of the Brazilian independence, in the years of its $150^{\text {th }}$ anninversary. It also became a convergence point of several different historical aspects, making it an important work for Brazilian cinema. Directed by Carlos Coimbra, seasoned director and main responsible for the "Cangaço Aesthetics" 21 in Brazilian cinema, was the last great production of Cinedistri, producer and distributor of national movies, created in 1949 by Osvaldo Massiani.

Cinedistri was responsible for several historical movies in Brazilian cinema, including O Pagador de Promessas (1962) and Lampião, o Rei do Cangaço (1964), the latter also directed by Carlos Coimbra. Such movies initiated the third wave of the production company, or its golden age, when it installed its headquarters in São Paulo in the quarter known as "boca do lixo"22.

The production of Independencia ou Morte closed this so-called golden age and, besides the investment, the aesthetical results were not satisfactory, despite reached box office records in Brazil, with 2.957.083 spectators ${ }^{23}$. Although well-known for most Brazilians, the plot tells, in a didactic way, the epopee of one single character D. Pedro de Alcântara, assisted by his mentor, José Bonifácio de Andrada e Silva, in the hard path of declaring the Brazilian independence. The story develops during the time in which D. Pedro was the regent prince after the return of the Portuguese royal family to Portugal ${ }^{24}$, and a series of facts end up leading the disconnection of Brazil from that kingdom.

The tangled story of Brazilian independence was analysed by a succession of researchers who demonstrated the diversity and plurality of forces involved in the process $^{25}$. Nonetheless, the official narrative of the military government, thought through

\footnotetext{
${ }^{20}$ The "Brazilian Miracle" is the term used to refer to a period of notable economic growth, exceptional repression and torture, and of histrionic patriotism encouraged by the military government, from 1969 to 1973 .

21 The "Cangaço Aesthetics" is part of a major Braziilian movement in film called "Cinema Novo" (New Cinema), occurred mainly during the 1960s. Cangaço was a form of "Social Banditry" and had very particular aesthetic and political features, which led to be recovered by Brazilian artists and intellectuals as a form of redemption of the marginalised part of Brazilian history.

${ }^{22}$ Fernão Ramos; Luís Felipe Miranda. Enciclopédia do Cinema Brasileiro (São Paulo: Editora do Senac, 2004), $132-133$.

${ }^{23}$ Antônio Leão da Silva Neto. Dicionário de Filmes Brasileiros (São Paulo: Ed. do Autor, 2002).

${ }^{24}$ Fleeing from the Peninsular War, the Portuguese royal family transported the Court to Brazil in 1808, coming back to Portugal in 1821 by pressure of the Portuguese Liberal Revolution.

${ }_{25}$ Charles Ralph Boxer, A idade de ouro do Brasil: dores de crescimento de uma sociedade colonial (São Paulo: Companhia Editora Nacional, 1963); Jorge Caldeira org., José Bonifácio de Andrada e Silva (Coleção "Formadores do Brasil" (São Paulo: Editora 34, 2002); Maria Odila Leite da Silva Dias, A interiorização da metrópole e outros estudos (São Paulo: Alameda Casa Editorial, 2005); Raymundo Faoro intr. e org., O debate político no processo da Independência (Rio de Janeiro: Conselho Federal de Cultura, 1973); Faoro intr. e org., O debate político no processo da Independência (Rio de Janeiro: Conselho Federal de Cultura, 1973); João Luís Ribeiro Fragoso, Homens de grossa aventura:
} 
newly born school topics life "moral and civic education", sought for a story without political disputes, focusing on personal struggles, and reverberating the official story that would fit like a glove in the propaganda machine of the General Médici government:

[...] it was not limited to repression. It [the propaganda machine] distinguished clearly between a significant, but minoritarian, branch of society, opposed to the regime, and the herd living everyday life with some hope in those years of economic prosperity. The repression ended up with the first sector, while the propaganda was charged to, at least, neutralize, the second ${ }^{26}$.

Thus, it was also in the Grande Oriente do Brasil $^{27}$ best interests to connect its image to the military government. This masonic body was living a period of intense internal struggle for power, and that through its majoritarian ward was trying to purge members who manifested traces of plurality in their political mindset, common in the political order prior to 1964. Given the political national atmosphere, opinions on matters of politics were becoming more uniform and people in power inside Freemasonry were using well the conveniences of that moment ${ }^{28}$.

The Grande Oriente do Brasil ceded the main temple in its principal building, the Palácio do Lavradio, besides regalia (aprons, jewels and sashes), for the filming of the Masonic meetings, an unusual attitude for the hitherto reserved Brazilian Freemasonry. However, to be pictured as heroes of Brazilian independence would be a great opportunity to figure with a good image in front of the public, and at the same time, to reinforce the image of collaboration with the military regime. In the light of these aspects, one dialogue becomes illustrative of the ambiguous role of Freemasonry in Brazilian history. The dialogue happens between D. Pedro, regent prince, and Friar Habner, one of his counsellors

Friar Habner: Do you know that the Masonic lodge which Dom João VI had closed have reopened?

D. Pedro: All the citizens of this country are free in their actions Friar Habner.

Friar Habner: Since they don't circumvent the principles of the regime your highness!

D. Pedro: The Freemasons are useful to the regime.

acumulação e hierarquia na praça mercantil do Rio de Janeiro (1790-1830) (Rio de Janeiro: Arquivo Nacional, 1992); Lúcia Maria Bastos Pereira das Neves, Corcundas e constitucionais: a cultura política da Independência (1820-1822) (Rio de Janeiro: Revan, Faperj, 2003).

${ }^{26}$ Boris Fausto, História do Brasil (São Paulo: EDUSP, 2003), 484.

${ }^{27}$ The Grande Oriente do Brasil was, and still is, the biggest masonic organization in Brazil. This masonic body also claims to be the continuation of the Grande Oriente Brasilico that was shut by Dom Pedro still in 1822. Nevertheless, neither of these names is mentioned in the movie.

${ }^{28}$ Octacílio Schüler Sobrinho, Uma Luz na História: o sentido e a formação da COMAB (Florianópolis: Editora O Prumo, 1998); José Castellani, Os maçons na independência do Brasil (Londrina: Editora maçônica “A Trolha” Ltda. 1993). 
Friar Habner: They are dangerous, insidious, they act in the shadows...

Thenceforth, three sequences where Freemasonry appears are interspersed. In the first one, right after the above dialogue, there is a re-enactment of what would have been the extraordinary (specially convened) session of the Masonic lodge Comércio e Artes. Truly, this Masonic lodge is the one in which the then regent prince was initiated, in $2^{\text {nd }}$ August 1822. In that scene, the Orator $^{29}$, Joaquim Gonçalves Ledo ${ }^{30}$, pumps the Freemasons up for standing against the new exigences of the Portuguese Parliament. Right after, José Bonifácio, Dom Pedro's mentor is shown protesting against the return of the prince to Portugal, as commanded by the Metropolitan Parliament, and then another Freemason supporting the same idea, still inside the Masonic meeting.
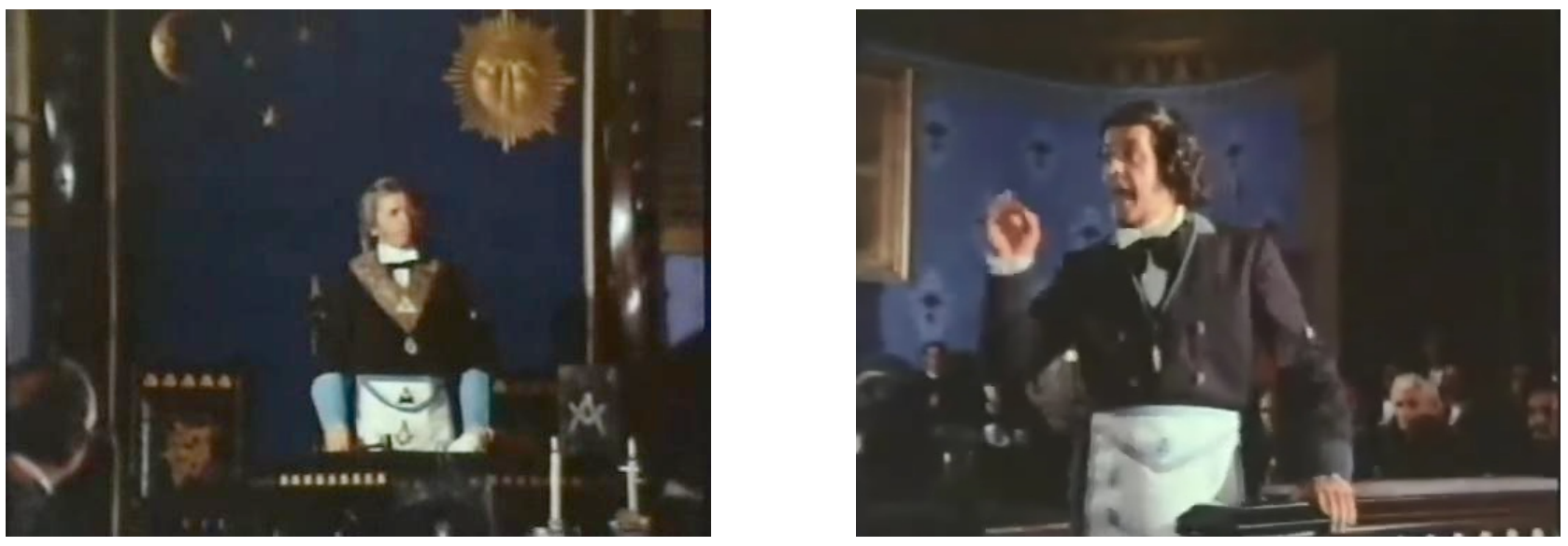

(Above) The Masonic meetings, filmed inside the Main Temple, helped the movie aesthetically, also giving it historical accuracy, nevertheless, it also reinforced the connection of Brazilian Freemasonry with the celebrations of the $150^{\text {th }}$ Anniversary of the independence and the military government.

Next, there is a sequence of special importance, a group of Freemasons, led by Gonçalves Ledo, appears plotting to overthrow José Bonifácio from the chair of Grand Master. Additionally, they plan to offer to Dom Pedro, the title of "Perpetual Defensor and Protector of Brazil", as well as initiating him in Freemasonry in order to appoint him as Grand Master afterwards. Is in this moment that occurs, without an explicit narrative, the construction of an ambiguous role for the masonic group. Fortwith, Dom Pedro emerge inside a Masonic lodge, being invested as Grand Master by Gonçalves Ledo.

\footnotetext{
${ }^{29}$ One of the Masonic officers of the lodge.

${ }^{30}$ It is important to remark that Joaquim Gonçalves Ledo, was the head of a group who desired a more Constitutional approach to a future Brazilian monarchy. This group, initiated Dom Pedro in Freemasonry hoping to influence the regent prince, only to find themselves, later, persecuted by the then Emperor of Brazil.
} 
Under those circumstances, it is significative that the next scene is the peak of the movie, the one in which Dom Pedro declares Brazilian independence. This scene as all the historical moments, like the coronation, are portrayed as the classic canvasses painted, mainly, by the painter Pedro Américo. It is worth saying that Américo painted this canvas (Independence or Death), decades after the event, being presented in 1888 - one year before the proclamation of the Brazilian republic - following a classic composition method and far from historical accuracy regarding characters and clothes. In the picture, and hence the movie, Dom Pedro declares independence on the banks of Ipiranga river, in a gala uniform, mounted in a white horse. It must be remembered that Dom Pedro was invested as Grand Master of the Grande Oriente Brasilico (do Brasil) after the declaration of independence and not before as the movie implies ${ }^{31}$.

After the "cry of Ipiranga" scene, in the remaining 60 minutes of the movie, the subject of Freemasonry does not show up again. More than a silence, or a flawed script, the gap is backed by history. Dom Pedro, after taking his oath as Grand Master, suspended the meetings of the Grande Oriente Brasílico and its lodges in 1822; the Masonic body would come back to life as Grande Oriente do Brasil only in 1831.

Although it may not have been the intention of the director Carlos Coimbra, the movie Independência ou Morte was perfectly suited to the propaganda machine of Brazilian military dictatorship. The celebrations of the $150^{\text {th }}$ anniversary of the independence was a crucial moment of the political program of the General Médici government, as explained by historian Daniel Aarão Reis:

It was the "golden years", of continuous progress, of broadening horizons and patriotic celebration, that reached its peak between 1970 and 1972, when the nation celebrated the third world title in the football world cup and celebrated the $150^{\text {th }}$ anniversary of its independence, with one more international footballing title ${ }^{32}$.

\section{Un Borghese Piccolo Piccolo (1977) - The mafia of the mediocre}

To interpret the nineteen seventies in Italy is a hard task to any historian. Beyond the question if it was a state of exception, it is undeniable the existing tension in that country during what Pierre Milza called "leaden years"33. The action of the red brigades was jumbled with a political regime that created a series of "special laws" to judge political

\footnotetext{
${ }^{31}$ Pedro de Alcântara, under the symbolic name of Guatimozin, took his oath as Grand Master in October $4^{\text {th }}, 1822$ (José Castellani. "Os maçons na independência", 81).

32 Daniel Aarão Reis, “A vida Política”. In Modernização, Ditadura e Democracia: 1964- 2010. Coordinated by Daniel Aarão Reis (Rio de Janeiro: Fundación Mapfre e Editora Objetiva, 2014), 90.

${ }^{33}$ Pierre Milza, Histoire de l'Italie : Des origines à nos jours (Paris: Fayard, 2005), 995.
} 
crimes, as pointed out by Giorgio Agamben ${ }^{34}$. Denying the climate of political dispute, or even civil war, Italy searched a normality that turned out inciting even more tension between the two political horizons that presented itself at the time.

In the meantime, Italian Freemasonry also hinged in two currents, basically conservatives and liberals. It is important to realize that Italy was the cradle of the Carbonaria or "florestal Freemasonry", that different of its co-sister, Freemasonry, was built with explicit political purposes in the $18^{\text {th }}$ century. Nevertheless, in the $1970 \mathrm{~s}$, regular Freemasonry, in its majority, went down the political conservatism, and as well-known, a minority in the extreme right produced scandals that would burst in the following decade, like the one of the Masonic lodge Propaganda Due, the famous $\mathrm{P} 2^{35}$.

It is in this context that director Mario Monicelli adapts the work of Vicenzo Cerami, Un Borghese Piccolo Piccolo, making of it a caustic portrait of the Italian petty bourgeoisie in its higher expression in the seventies: the public servants. The movie tells the story of Giovanni Vivaldi ${ }^{36}$, a subservient civil servant of an Italian Social Security Institute. Vivaldi has an adoration for his boss, Dr. Spazioni ${ }^{37}$, and nurtures an equal esteem for his only child, an unremarkable boy who manages to graduate, with passable marks, as an accountant. In a tragicomic way, both sides of Giovani Vivaldi`s bourgeoise behaviour starts to show, on one hand the pettiness, through his habit of bowing down when in the presence of any superior, on the other hand a darker side, unstable, insulting anyone who puts itself in front of him in traffic, for instance.

One of Vivaldi's goals in life is to put his soon, the newly graduated accountant, in the same social security institute in which he works. However, to do so, the boy needs to be approved in the dreaded public tender. Vivaldi seeks a way to put his son into the institute without the necessity of being approved in the public tender, and for that asks his beloved boss, Dr. Spazioni, who tells him that there is no other way, that times had changed, and that now everyone must go through the public selection. Before Vivaldi's insistence, Dr. Spazioni lets him know that there is a way of easing things, and at this point he asks "What do you know about Freemasonry?"

Henceforth, a series of hilarious events take place, in which Giovanni Vivaldi instruct himself, through booklets, on Freemasonry. In due time, he goes to his initiation, but first we testify the conflict present in his mind, proving that even after the booklets, Freemasonry was still a slippery slope within his (and the traditional society) values. Before

\footnotetext{
${ }^{34}$ Giorgo Agamben, "Do bom uso da memória e do esquecimento". In Exílio (seguido de valor e afeto) by Toni Negri (São Paulo, Editora Iluminuras Ltda, 2001).

${ }^{35}$ The Masonic lodge Propaganda Due, due to its illicit activities was expelled from the Grande Oriented'Italia in 1976. However, the lodge continued, illegally, its activities, infiltrating its members in the three branches of power, as well as the Vatican and the Mafia. Its scams were uncovered by a Parliamentary Investigation Committee being even characterized as "a state inside the state".

${ }^{36}$ Interpreted by Alberto Sordi.

${ }^{37}$ Interpreted by Romolo Valli.
} 
leaving the house, heading to the ceremony, Vivaldi goes to the bathroom, sits on the toilet and talks to God, asking for forgiveness, and explaining he was doing that "just because of his son".

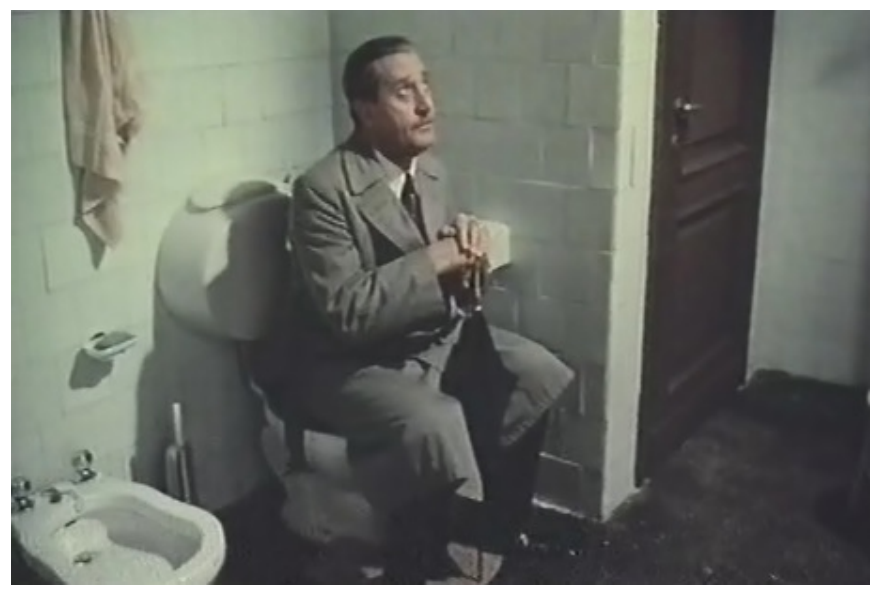

(Above) Before going to his initiation, Giovanni Vivaldi goes to the bathroom to ask God for forgiveness.

After his funny initiation, with some "Bobby Bumps" moments, Giovanni Vivaldi is received by his "mentor", Dr. Spazioni, that gives a memorable welcome speech in which, in a metalinguistic way, there is the very denial of the propelled masonic equality:

Dr. Spazioni: For the Freemasonry, every weak sentiment is cowardice. Every free will is a crime, remember that, Brother Mason Apprentice. The symbol of the compass is clear, it draws a circle. You're now the smallest circle. But even you will become great, little by little. This doesn't mean you're inferior, no! You're always a circle, as drawn by the compass. Thus, you're a brother, one like us. In this sense, Freemasonry is egalitarian. The great ones have great rights, you have them on a smaller scale. But those rights are yours! Is that clear? In short brother, you are welcome among us.

Further, Dr. Spazioni gives Vivaldi the answer key to the test that his son will take. Mario, Vivaldi's son, decorates the answers with extreme difficulty, giving an illustration of his obtuseness. Nevertheless, their petite bourgeoisie lives would soon be crossed, literally and figuratively, by Italian's troubled political and social scene that occurred from the late sixties until the early eighties, a period known as anni di piombo (the led years). On their way to the test, they are crossed by bank robbers, a stray bullet hits Mario on the head, who dies instantly. Forthwith, Giovanni Vivaldi stops being portraited as a quiet bourgeois to outlet his aggressiveness. 


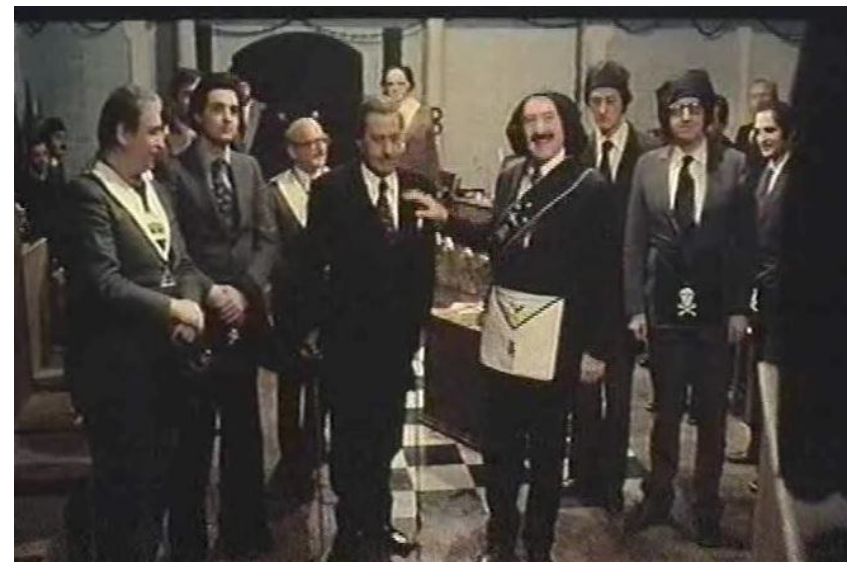

(Above) Vivaldi is recaptioned by Dr. Spazioni.

This major setback that leads us to the climax, portrays Freemasonry as being one more palliative before an unequal society, something that Louis Althusser would call "an ideological states' apparatus". Despite his intentions when initiated, Vivaldi does not achieve any other privilege for being a Freemason. Emblematic is the scene in which he asks to a brother of his masonic lodge, who is responsible for the cemetery, to rush the burial of his son in a proper grave. Meanwhile, the corpse of his son awaits among many others, in a sort of deposit that director Monicelli depicts in great resemblance to Dante's purgatory.

The Freemason who administrates the queue informs that there is nothing that he can do since there is "more important" people to push in the waiting list, cardinals, deputies, ministers, etc. Facing that news, Vivaldi and the other mason make what is supposed to be a masonic sign to each other with an air of quiet desperation. Thus, it was shown that the masonic fraternity is maybe unachievable in a system that overlaps privileges.

Monicelli's movie shows maybe the most interesting, and maybe realistic, face of Freemasonry in the 1970s, and maybe suitable for many Freemasonries today. In other words, the movie depicts Freemasonry as a structure capable of soften the middle class so that they maintain the status quo, oddly using an institution that in the Italian past fought against oppression and inequality. Ultimately, Giovanni Vivaldi is the archetypical bourgeois, offering a comic vision of the tragic dream of fraternity and belonging facing a capitalistic society in the twentieth century.

\section{Conclusion}

More than reflect the presence of Freemasonry within society, these representations of the Craft in cinema built, and build, the perceptions that the public, and even 
Freemasons, have of Freemasonry. Historians, Freemasons and aficionados have lists and lists about movies in which Freemasonry is the theme, the back story or movies in which the fraternity is not more than mentioned.

The aim here was to briefly analyse three movies in which Freemasonry was serving some kind of purpose in states of exception. In the first one, Les Forces Occultes, Freemasonry is portraited as one element of the Jewish-communist conspiracy; the movie conveys the idea of a mischievous fraternity which recruits people to transform them in puppets of a bigger plan. It suited perfectly the Nazi propaganda machine and its narrative of a world divided between good and evil.

The second, Independencia ou Morte, was tailor made for the $150^{\text {th }}$ anniversary of Brazilian independency occurred during the most violent period of the Brazilian military dictatorship that took place between 1964 and 1985. The movie reflects the dubious attitude of the regime towards Freemasonry, at the same time that the Freemasons would get closer to the regime, giving it support through manifestos endorsing the military and decorations to its main figures, ${ }^{38}$ the regime was watching closely the masonic activities with apprehension as the repression archives show us.

Un Borghese piccolo piccolo, by its turn, represents the inverse of the previous ones. Instead of serving some purpose of the established regime, it promotes its very critics. The character of Giovanni Vivaldi embodied the Italian society in a comic way and exposes the inconsistences of Freemasonry with the crudeness of social criticism. It is worth to mention that Mario Monicelli was not a newcomer; seasoned director and screenwriter, he managed to portray Freemasonry as "the mafia of the mediocre" 39 , even before this epithet arise in England during the nineteen eighties.

Overall, it can be affirmed that more than a threat or guardians of any political structure, the Freemasons are useful to regimes, mainly states of exception; whether supporting it, or making a nice scapegoat, or even posing an imagined danger for what one holds sacred. The magic of cinema helped, and still helps, to enhance those feelings by portraying Freemasonry in the most convenient apparel for the occasion, intentionally with a clear purpose or unintentionally, reverberating preconceived notions.

However, it is undeniable that the popularised imagery related to Freemasonry is mostly derived from movies and series, at least for the generation interval between baby boomers and millennials. More than mere curiosity, these productions shaped the public image of Freemasonry in such a way that this image produced on screen over time became more truthful than any masonic attempt to "come out". One of these attempts, the documentary "Inside the Freemasons" reached a broader audience by showing the

\footnotetext{
${ }^{38}$ Octacílio Schüler Sobrinho, Uma Luz na História: o sentido e a formação da COMAB (Florianópolis: Editora O Prumo, 1998), 483-510.

${ }^{39}$ Expression used in the British TV series "Our Friends in the North" and that soon became a way to refer to Freemasonry in England during the 1980s.
} 
backstage of English Freemasonry and its prosaic existence. The question opened to future historians, that will have the privilege of hindsight, is to evaluate if the - sometime tedious reality, make its way over the colourful and convenient conspiracy theories.

\section{Bibliography}

Agamben, Giorgio. "Do bom uso da memória e do esquecimento". In Exílio (seguido de valor e afeto). Edited by Toni Negri. São Paulo, Editora Iluminuras Ltda, 2001.

Boxer, Charles Ralph. A idade de ouro do Brasil: dores de crescimento de uma sociedade colonial. São Paulo: Companhia Editora Nacional, 1963.

Caldeira, Jorge org. José Bonifácio de Andrada e Silva. Coleção "Formadores do Brasil". São Paulo: Editora 34, 2002.

Castellani, José. Os maçons na independência do Brasil. Londrina: Editora maçônica "A Trolha" Ltda., 1993.

Chevassu, F. "Forces Occultes". Image et Son: La Revue do Cinema. Paris: Union Française des Oeuvres Laïques d'Éducation par l'Image et par le Son, numero 188 (novembre, 1965).

Daniel, James W. "UGLE External Relations 1950-2000: policy and practice". In Ars Quatuor Coronatorum, 117 (2005): 1- 47

Dias, Maria Odila Leite da Silva. A interiorização da metrópole e outros estudos. São Paulo: Alameda Casa Editorial, 2005.

Faoro, Raymundo intr. e org. O debate político no processo da Independência. Rio de Janeiro: Conselho Federal de Cultura, 1973.

Fausto, Boris. História do Brasil. São Paulo: EDUSP, 2003.

Fragoso, João Luís Ribeiro. Homens de grossa aventura: acumulação e hierarquia na praça mercantil do Rio de Janeiro (1790-1830). Rio de Janeiro: Arquivo Nacional, 1992.

Gardie, René org. Compreender o Cinema e as Imagens. Lisboa: Edições Texto \& Grafia, 2007.

Girardi, João Ivo. Do meio dia à meia noite: vade-mécum maçônico. Blumenau: Nova letra Gráfica e Editora, 2006.

Hobsbawm, Eric J. Mundos do Trabalho. Rio de Janeiro: Paz e Terra, 2000.

Milza, Pierre. Histoire de l'Italie: Des origines à nos jours. Paris: Fayard, 2005.

Moen, Kristian. "Imagination and Natural Movement: The Bray Studios and the "Invention" of Animated Film. In Film History 27, no. 4 (2015): 130-150.

Moscovici, Serge. Representações Sociais: Investigações em Psicologia Social. Petrópolis: Vozes, 2009. 
Neves, Lúcia Maria Bastos Pereira das. Corcundas e constitucionais: a cultura política da Independência (1820-1822). Rio de Janeiro: Revan, Faperj, 2003.

Prescott, Andrew and Susan Sommers. "Searching for the apple tree: revisiting the earliest years of organised English freemasonry". In Reflections on Three Hundred Years of Freemasonry: Papers from the QC Tercentenary Conference. Edited by John Wade. London: Lewis Masonic, 2017.

Ramos, Fernão and Luís Felipe Miranda. Enciclopédia do Cinema Brasileiro. São Paulo: Editora do Senac, 2004.

Reis, Daniel Aarão. “A vida Política”. In Modernização, Ditadura e Democracia: 19642010. Coordinated by Daniel Aarão Reis. Rio de Janeiro: Fundación Mapfre e Editora Objetiva, 2014.

Rudé, George. Hanoverian London 1714-1808. London: Secker \& Warburg, 1971.

Schüler Sobrinho, Octacílio. Uma Luz na História: o sentido e a formação da COMAB. Florianópolis: Editora O Prumo, 1998.

Silva Neto, Antônio Leão da. Dicionário de Filmes Brasileiros. São Paulo: Ed. do Autor, 2002.

Snoek, Jan A.M. "Framing Masonic Ceremonies". In Rituale in Bewegung. Rahmungs und Reflexivitätsprozesse in Kulturen der Gegenwart. Edited by H. Jungaberle and J. Weinhold. Berlin: LIT, 2006.

Stevenson, David. The Origins of Freemasonry Scotland's Century, 1590-1710. Cambridge: Cambridge University Press, 1990. 